\title{
Metafísica em tempos de pandemia: consolo schopenhaueriano para o espanto em face da morte
}

\author{
Metaphysics in the Times of a Pandemic: Schopenhauerian Consolation for the \\ Astonishment in the face of Death
}

\section{Gleisy Tatiana Picoli}

Resumo: 0 ponto central do presente artigo consiste em aplicar o conceito schopenhaueriano de metafísica ao contexto atual da pandemia de covid-19, com o intuito principal de proporcionar um consolo ao indivíduo angustiado com medo da morte.

Palavras-chave: Metafísica; Pandemia; Morte; Schopenhauer; Religião; Medo

Abstract: This article applies the Schopenhauerian concept of metaphysics to comfort anguished individuals fearing death, particularly in the context of the COVID-19 pandemic.

Keywords: Metaphysics; Pandemic; Death; Schopenhauer; Religion; Fear

"A morte é propriamente dizendo o gênio inspirador ou o Musagete da filosofia, pelo que Sócrates também definiu a

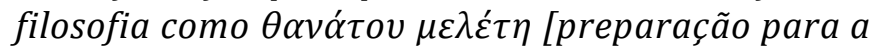
morte]. Dificilmente ter-se-ia filosofado sem a morte." (W

II, cap. 41, 555)

Nas atuais discussões filosóficas sobre a pandemia de covid-19, vemos comumente pensadores duelarem suas perspectivas sobre o futuro pós-coronavírus; mas nós, em outro sentido, abordaremos a filosofia de Schopenhauer não para argumentar no âmbito da filosofia política, e sim para destacar o profícuo papel da metafísica ao indivíduo amedrontado com a certeza da morte. A pandemia trouxe a algumas pessoas uma maior clareza acerca da finitude da própria existência e, por conseguinte, um terrível medo da morte, o qual dificilmente será sanado só com opiniões políticas, que são relativas e muitas delas errôneas, como o próprio futuro mostrará. 0 conceito schopenhaueriano de metafísica, por sua vez, fornece ao indivíduo o verdadeiro abrigo, ao qual ele pode recorrer a qualquer momento de sua vida, mesmo se ele fosse capaz de viver por milhares de anos. Aliás, a meta superior do que Schopenhauer chama de "filosofia real" consiste precisamente em dar uma satisfação sobre a necessidade metafísica do ser humano, ou seja, dar "um clareamento sobre esta enigmática existência, na qual nada é claro senão a sua miséria e vaidade" (W II, cap.17, 199-200). Mas, à luz de Barboza, já advertimos de que, em se tratando de Schopenhauer, o que temos é uma filosofia do consoloํ․

${ }^{1}$ BARBOZA, Schopenhauer: a decifração do enigma do mundo, 6. 


\section{A origem do medo da morte}

Numa passagem do capítulo 41 do segundo tomo d'O Mundo, Schopenhauer escreve sobre a verdadeira fonte do medo da morte, o autor então defende que ela é proveniente da parte volitiva do nosso ser, e não da parte cognoscente, como podemos conferir abaixo:

o grande apego à vida, ou antes o medo da morte, de modo algum origina-se do CONHECIMENTO, que nesse caso seria o resultado do reconhecimento do valor da vida; mas, em vez disso, o medo da morte enraíza-se diretamente na VONTADE, provém de sua essência originária, que é desprovida de conhecimento e, por conseguinte, cega Vontade de vida. Assim como somos seduzidos pela vida devido ao impulso totalmente ilusório da volúpia, do mesmo modo agarramo-nos à vida pelo medo, também por certo ilusório, da morte. Ambos originam-se de modo imediato da vontade, que é em si desprovida de conhecimento. (W II, cap. 41, 595).

$\mathrm{Na}$ visão schopenhaueriana, o medo da morte tem a sua origem na nossa essência, a vontade de vida, e jamais proviria do nosso intelecto. Para Schopenhauer, a vontade, a qual constitui o núcleo do nosso ser e, ao mesmo tempo, o princípio da existência do mundo é originariamente cega, irracional e sem consciência, sua essência consiste simplesmente em querer. Quem conhece as coisas é o intelecto, o qual, por sua vez, não é capaz de querer. Em suma: a vontade quer, mas não conhece nada; o intelecto conhece, mas não quer nada. Desse modo, a vontade só consegue sair, de fato, de sua cegueira inconsciente por meio do intelecto, do sujeito do conhecer. Mas, no fundo, o que o intelecto faz é obedecer às ordens da vontade, clareando os motivos para que ela atinja os seus fins, ou, de outro modo, nas palavras de Janaway: "o intelecto é consciente, constituindo a nossa janela para o mundo, porém, a força motriz que nos leva ao lugar para o qual vamos se acha num plano mais profundo da psique, no interior do organismo que também somos"2. É por isso que Schopenhauer diz, repetidamente, que o intelecto é um mero servo da vontade (W I, § 27, 177; W II, cap. 19, 252, dentre outras). Mas, embora considere a vontade o elemento primário nos seres humanos - "a vontade é metafísica, o intelecto, físico" (W II, cap. 19, 243), afirma Schopenhauer, que atribui assim ao intelecto, o papel secundário -, o nosso autor não deixa de reconhecer o quanto um precisa do outro, como podemos conferir na seguinte metáfora: "a comparação mais notável para a relação entre ambos é a do forte cego que carrega nos ombros o paralítico que vê" (Id., 253).

Como a vontade depende do intelecto do indivíduo para conhecer algo, é de se esperar, portanto, que ela creia na ilusão produzida pelo principium individuatianis de que, se o indivíduo morrer, ela também morre. Segundo Schopenhauer, para todo sujeito que conhece, ele se considera "o único indivíduo real no mundo, isto é, o único fenômeno da vontade, e o único objeto imediato do sujeito" (W I, § 19, 121), seus semelhantes são, para ele, meras representações; e é precisamente tal conhecimento que é passado à vontade de cada um. É por isso que a vontade, que é ímpeto cego para a existência, se horroriza tanto com aquilo que vê através do indivíduo, pois a sua possível aniquilação representa-lhe o verdadeiro oposto da sua essência originária. Sabemos, porém, que, conforme a doutrina schopenhaueriana, o que, de fato, desaparece com a morte do indivíduo é tão somente o seu corpo, a sua aparência,

2 JANAWAY, Schopenhauer, 73. 
nunca a sua essência ${ }^{3}$. Por isso, para Schopenhauer, esse temor da vontade não faz o menor sentido, e constitui até mesmo um espetáculo estranho e risível (W II, cap. 41, 598), uma vez que ela, a essência íntima do mundo, jamais sucumbirá, pois é ela que sustenta todo o mundo e toda existência (e não o contrário).

Da perspectiva do indivíduo, em virtude de sua parte volitiva, podemos dizer então que não há dúvidas de que a morte é a pior coisa do mundo, o maior de todos os males. É por isso que choramos intensamente a morte dos que amamos, pois acreditamos que uma grande desgraça lhes aconteceu; e é pelo mesmo motivo que condenamos "como duro de coração e desprovido de amor aquele que, em tais casos, não chora nem mostra aflição" (Id., 557). Por esse mesmo motivo, quando temos sede de vingança, em seu grau mais elevado, desejamos a morte dos nossos inimigos, porque, na nossa visão, é o pior que lhes poderia acontecer. Mas Schopenhauer pensa diferente. "Se o ser humano fosse, ao contrário, um mero ser QUE CONHECE", escreve Schopenhauer, "então a morte teria de ser para ele não apenas indiferente, mas até mesmo bem-vinda" (Id., 595). Sabemos muito bem o quanto o nosso autor não economiza nas suas críticas ao mundo em que vivemos. A vida, aos olhos de Schopenhauer, não passa de uma série sucessiva de dores e sofrimentos infindáveis, a qual está diretamente associada à nossa necessidade essencial. A nossa essência, a vontade, quer o tempo todo, por isso, nós passamos a vida toda perseguindo incessantemente os seus fins, o que nos torna meros joguetes nas suas mãos. Mas, com a chegada da morte, finalmente, libertamo-nos dessa vida de sofrimento. A morte, portanto, põe fim à nossa infelicidade, nome dado em oposição àquilo que normalmente chamamos de felicidade ou satisfação, que, na visão schopenhaueriana, "nada é senão a liberação de uma dor, de uma necessidade" (W I, § 58, 370). Desse modo, a infelicidade constitui, para Schopenhauer, a regra da vida; e a felicidade, a exceção. E para piorar a nossa situação neste mundo, a felicidade ou contentamento, na verdade, não é algo duradouro para nós, porque tão logo temos um desejo satisfeito, estamos atrás de um outro. Por isso, a máxima schopenhaueriana: "toda vida é sofrimento" (W I, § 56, 360). E assim compreendemos por que, para Schopenhauer, o medo da morte, ou o apego à vida, de modo algum, tem a sua origem no intelecto. Se acaso pudéssemos contar unicamente com o conhecimento, numa análise fria da vida, sem qualquer influência da vontade, Schopenhauer nos assegura de que jamais nos apegaríamos à vida.

\section{Como dizer "vai ficar tudo bem!" no pior dos mundos possíveis?}

Consideraremos a morte agora, não do viés individual, e sim do todo, para analisar em que medida ela afeta a natureza. Sobre esse ponto, Schopenhauer observa que a natureza, a qual chama de Grande Mãe, envia seus filhos, sem nenhum cuidado ou proteção, de encontro aos mil perigos ameaçadores, por isso, o autor é peremptório em dizer que essa indiferença da natureza mostra, com efeito, que a morte dos indivíduos não a afeta em simplesmente nada. Na realidade, a declaração da natureza é a seguinte:

a morte ou a vida do indivíduo não têm valor. 0 que a natureza o exprime abandonando a vida de cada animal bem como a de cada ser humano aos acasos mais insignificantes, sem intervir pelo seu salvamento. - Considerai o inseto no vosso caminho: uma pequena, inconsciente mudança do vosso passo é decisiva para a vida ou a morte dele. (...) na medida em que a natureza abandona os seus organismos tão indizivelmente engenhosos não apenas à voracidade do mais forte mas também ao acaso mais cego, ao humor de cada

\footnotetext{
3 De acordo com Schopenhauer, a cada renascimento, o indivíduo recebe um novo intelecto e assim não tem recordação alguma de uma existência anterior; o que renasce, na verdade, é a vontade em si individual, sua parte eterna e indestrutível. Por isso, na visão schopenhaueriana, a palavra mais precisa para designar tal doutrina é palingenesia, e não metempsicose. Para mais detalhes sobre esse assunto, ver: W II, cap.41, 600.
} 
louco e ao capricho de cada criança, ela exprime que o aniquilamento desses indivíduos lhe é indiferente, não a prejudica, não significa nada, e que, nesses casos, o efeito importa tão pouco quanto a causa. (...) Ela se comporta com os humanos do mesmo modo que com os animais. Sua declaração, portanto, contém isto: vida ou morte do indivíduo lhe são indiferentes (W II, cap.41, 567-568)

No fundo, a confiança da natureza de que tudo ficará bem provém da espécie em geral, a única com a qual a natureza realmente se preocupa, segundo o nosso autor. Se a espécie estiver a salvo, não há nada o que temer, mesmo com tantas mortes. Vale lembrar que, para Schopenhauer, as espécies da natureza correspondem às Ideias platônicas, ou seja, são formas arquetípicas de todas as coisas que existem no mundo, mas, ao contrário das coisas sensíveis, as Ideias não estão submetidas a nenhum devir ou perecer. As Ideias não nascem, nem morrem, nunca sucumbem, porque não existem no tempo, espaço e causalidade. A vontade, aliás, que é Una e indivisível, multiplica-se em inúmeras aparências no mundo sensível precisamente através das Ideias. As coisas no mundo sensível, por sua vez, não passam de cópias (ou, na linguagem platônica, sombras) de suas próprias Ideias, e tais cópias (como toda aparência) são sempre efêmeras, como explica Barboza no exemplo a seguir:

os diversos gatos da realidade só existem enquanto reflexo distorcido de uma Ideia de gato inalterável, instituída pela Vontade num mundo imemorial. Todos os gatos do mundo não passam da pluralização de uma única e mesma Ideia de gato. Os gatos podem até desaparecer da superfície da Terra, mas a sua Ideia, eterna, não. Do mesmo modo, a totalidade dos cavalos pertencem à Ideia única de cavalo, são sua pluralização. E assim por diante. A humanidade mesma em sua globalidade é uma Ideia eterna, inalterável, embora os seus fenômenos, os muitos indivíduos, sejam passageiros ${ }^{4}$.

A partir desse ponto de vista, podemos imaginar que alguém possui um gato preto que foi cruelmente envenenado por um vizinho sem coração. 0 gato morreu e então a sua aparência desapareceu, mas não a Ideia de gato, que nunca desaparecerá. E assim como os gatos, nós seres humanos também desapareceremos um dia, mas, apesar disso, a Ideia de humanidade, da qual muitos outros seres humanos nascerão no nosso lugar, se seguirá inalterável e eterna. Por esse motivo, a natureza assiste placidamente, dia a dia, à morte de inúmeras aparências, sem nada temer.

Mas alguém poderia questionar se a natureza, no caso de uma pandemia, não estaria ameaçada, sobretudo no que tange à humanidade. Com base no capítulo 46 do segundo tomo d' $O$ Mundo, acreditamos que Schopenhauer responderia que não, não estaria ameaçada, pois este mundo foi feito de tal forma que ele é horrível na medida certa. De acordo com Schopenhauer, se o mundo fosse ligeiramente pior do que ele já é, a sua subsistência não seria possível, fato que o torna o pior dos mundos possíveis. Por isso, Schopenhauer nos assegura: "é claro que o mundo não pode ter sido construído de tal modo que estivesse ameaçado de colapsar a qualquer momento" (W II, cap.46, 694). No entanto, é muito comum vermos pessoas se sentirem ameaçadas com a ideia de um suposto fim do mundo. Contra perspectivas como essas, Schopenhauer objeta:

ora, este mundo foi de tal forma disposto, como teria de sê-lo, para poder se manter com a sua exata miséria: se, entretanto, ele fosse um pouquinho pior, então não poderia mais subsistir. Logo, um mundo pior, por ser incapaz de subsistir, é absolutamente impossível, por conseguinte, este é o pior dos mundos possíveis. Pois não apenas se os planetas batessem suas cabeças umas contra as outras, mas também se qualquer uma das perturbações ocorridas

\footnotetext{
${ }^{4}$ BARBOZA, Op. Cit., 53.
} 
atualmente em seu curso continuasse a aumentar, em vez de gradualmente compensarem-se entre si, o mundo deveria chegar rapidamente a um fim: os astrônomos (...) encontraram a duras penas através de cálculos que tudo sempre transcorrerá bem e o mundo poderá manter-se e seguir tal como é. Embora NEWTON fosse de opinião contrária, queremos esperar que os astrônomos não tenham errado em seus cálculos, portanto, que o mecânico perpetuum mobile (Motor perpétuo) que atua num tal sistema planetário não irá, como todos os outros, finalmente parar. (Id., 696)

0 fato de Schopenhauer acreditar na permanência deste mundo não significa, de modo algum, que tal fosse a sua preferência. De acordo com o nosso autor, se somarmos necessidade, dor e sofrimento de todo tipo, chegaremos à conclusão de que a inexistência do mundo seria preferível à sua existência (W II, cap.46, 688; W II, cap.17, 209; PP, §156, 270271). Mas se o fim do mundo não passa de uma ilusão e a humanidade não está se extinguindo aos poucos, por que, de tempos em tempos, aparece alguma ameaça química, biológica ou natural, resultando em milhões de mortes? Schopenhauer responde:

um terremoto em Lisboa, no Haiti, a destruição de Pompeia, não passam de pequenos sinais brincalhões (...). Uma tênue alteração da atmosfera, mesmo quimicamente indemonstrável, causa cólera, febre amarela, peste negra, e assim por diante, o que já ceifou milhões de pessoas: uma alteração só um pouco maior extinguiria toda vida. (W II, cap.41, 696)

Contudo, é evidente que, nessas situações, a quantidade de indivíduos mortos é muito alta, resultando assim num grande desfalque de seres vivos à natureza. Mas Schopenhauer nos mostra que a natureza sempre encontra uma solução para tudo. À luz dos estudos de Schnurrer e Casper, Schopenhauer defende que, nos lugares devastados por epidemias, a procriação aumenta na mesma proporção da mortalidade, como nos comprova a seguinte passagem:

de fato, há uma relação entre o aparecimento dos novos seres na vida e a morte dos que a deixam: essa relação mostra-se na grande fecundidade do gênero humano que se origina em consequência de epidemias devastadoras. Quando, no século XIV, a peste negra despovoou a maior parte do Velho Mundo, sucedeu-se uma fecundidade extraordinária do gênero humano, e o nascimento de gêmeos foi frequente: muito estranho foi nesta ocasião que nenhuma criança então nascida recebeu a dentição completa; a natureza, dispendendo muito esforço, era econômica nos detalhes. Isso o narra $\mathrm{F}$. SCHNURRER, Chronik der Seuchen, 1825. Também CASPER, em Über die wahrscheinliche Lebensdauer des Menschen, 1835, confirma o princípio de que o número de nascimentos, que vai sempre de par com a mortalidade, tem uma influência das mais decisivas sobre a duração de vida e sobre a mortalidade numa dada população, de modo que os casos de morte e nascimentos sempre, e em todos os lugares, aumentam e diminuem na mesma proporção, o que ele deixa fora de dúvida mediante inúmeras provas recolhidas em muitos países e suas diversas províncias. (WII, cap.41, 601).

Dessa forma, do ponto de vista schopenhaueriano, o bordão "vai ficar tudo bem", muito utilizado agora nas campanhas contra o covid-19, se empregado, deveria se referir unicamente à natureza. É apenas para ela que tudo sempre transcorrerá bem. Se pensarmos a partir da perspectiva do indivíduo, considerando o altíssimo número de mortes, bem como o sofrimento daqueles que inesperadamente perderam seus entes queridos, é claro que não vai ficar tudo bem. Além disso, voltar ao que era antes, isto é, à vida antes da pandemia, é estar ainda no pior dos mundos possíveis, de modo que também, nesse caso, não caberia dizer que tudo ficará bem. Decerto que Schopenhauer enxergaria, por trás desse bordão, um grande 
otimismo, o qual, segundo o autor, é "uma figura tão estranha neste palco do pecado, de sofrimento e de morte" (W II, cap.46, 695).

\section{Schopenhauer e a epidemia de cólera}

Ora, o indivíduo pode até analisar friamente os argumentos de Schopenhauer e convencer-se inteiramente de que a vida não vale a pena ser vivida. Mas, como vimos, de acordo com a doutrina schopenhaueriana, todo ser humano é composto não só de intelecto, mas também de vontade, de modo que "o medo da morte", como o autor mesmo ressalta, "permanece inexpugnável" (WII, cap.41, 596). O próprio Schopenhauer teve medo de morrer durante a epidemia de cólera, a qual assolou toda a Europa e infestou Berlim (cidade onde o filósofo morava) entre os anos de 1830/31. Pelo menos, é o que nos revela a seguinte passagem do manuscrito póstumo Cogitata:

E para servir à verdade em toda forma e até a morte, anoto que eu, na noite de ano novo, entre 1830 e 1831, tive o seguinte sonho, que aponta para minha morte no presente ano. - Do meu sexto ao meu sétimo ano, eu tive um amigo do peito e parceiro constante de jogo, exatamente da mesma idade, que se chamava Gottfried Jänisch e morreu, quando eu estava na França no meu décimo ano. Nos últimos trinta anos, provavelmente, pensei nele muito raramente. - Mas naquela noite, eu cheguei em uma terra desconhecida para mim; um grupo de homens estava em pé no campo e, entre eles, um adulto esbelto e comprido, que, eu não sei como, foi me apresentado como sendo precisamente aquele Gottfried Jänisch. Ele me deu boas-vindas. Esse sonho me motivou muito a deixar Berlim, na entrada da cólera em 1831: ele pode ter sido de verdade hipotética à então um aviso, isto é, se eu permanecesse, teria morrido de cólera. (Cogitata, [seite 245], 218-219).

Para outra pessoa, esse sonho poderia ser destituído de qualquer significado profundo, mas Schopenhauer acredita na natureza premonitória dos sonhos, e assim interpreta-o como um aviso para abandonar Berlim. Nosso autor foge então da cidade na qual, segundo Ziegler, cerca de 1400 pessoas morreram de cólera, de setembro de 1831 a fevereiro de $1832^{5}$. 0 filósofo Hegel, por sua vez, despreza esse expediente e morre três meses depois, vítima da epidemia de cólera, o que deixa Schopenhauer duplamente satisfeito: pela morte de seu adversário e pela sua salvação ${ }^{6}$. A nova cidade escolhida por Schopenhauer para morar é Frankfurt-am-Main, "primeiramente, por nenhuma outra razão senão a de que essa cidade, como lhe disseram, estava livre da cólera"7. Nesse período, de 1831 a 1832, Schopenhauer escreve o manuscrito Cholerabuch, que tem o referido título, como o próprio autor nos explica, "porque foi escrito durante a fuga da cólera" (Cholerabuch, 2). Nesse manuscrito, podemos encontrar inclusive receitas para se prevenir contra a cólera (Id., 162).

Vemos então que, durante o período da epidemia de cólera, Schopenhauer, de modo algum, fica de braços cruzados, esperando a morte chegar, contente com a ideia de que, se ele morresse, nada mudaria para natureza. Pelo contrário, o filósofo, defensor de que a morte pode ser uma amiga bem-vinda, teme pela própria morte, porque, para ele, como citamos alhures, o medo da morte é algo inexpugnável. Além de sua fuga, as receitas do Cholerabuch

\footnotetext{
${ }^{5}$ Cf. Ziegler. In: SCHOPENHAUER, Cholerabuch, 15.

${ }^{6}$ Weissmann, Vida de Schopenhauer, 115.

7 Safranski, Schopenhauer und die wilden Jahre der Philosophie, 416. Gwinner já observara que Schopenhauer escolheu Frankfurt, não por causa dos frankfurtianos, mas unicamente por uma questão de conforto e saúde, pois ele queria uma situação livre da cólera: GWINNER. Arthur Schopenhauer aus persönlichem Umgang dargestellt, 65.
} 
podem indicar também os cuidados tomados pelo autor para não sucumbir à epidemia. Sua atitude chega até mesmo a espantar sua irmã Adele, que lhe pergunta em carta por que Arthur se apegou tanto à vida e fugiu repleto de medo da cólera ${ }^{8}$.

\section{Fica em casa! No abrigo de uma metafísica}

Além das medidas preventivas, o que mais nos resta contra aquele insuperável medo da morte? Para nós, indivíduos abandonados à própria sorte pela Grande Mãe, atormentados pela certeza da morte e incerteza do destino e, além disso, cientes de que nossa morte não afeta em absolutamente nada o andamento do mundo, Schopenhauer aponta-nos um consolo, a saber: a metafísica. Se existe um remédio schopenhaueriano para aliviar o espanto em face da morte - o qual tende a se agravar em tempos de pandemia, porque, nessas situações, a morte nos aparece de forma mais evidente -, é a metafísica, cuja definição é dada por Schopenhauer nas seguintes palavras:

por METAFÍSICA entendo todo assim chamado conhecimento que vai mais além da possibilidade da experiência, logo, mais além da natureza, ou aparência dada das coisas, para fornecer um clareamento sobre aquilo através do que, em um ou outro sentido, estaríamos condicionados; ou, para falar em termos populares, sobre aquilo que se esconde atrás da natureza e a torna possível. (W II, cap.17, p.200).

Vale lembrar que Schopenhauer, de modo algum, considera aquilo que está por trás das aparências como algo independente delas, pois sua metafísica não permite a existência de outros mundos. Como observa Cacciola, "ao considerar a coisa-em-si como Vontade e esta como imanente ao mundo, ele [Schopenhauer] pretende não apenas completar a filosofia kantiana, dotando-a de uma metafísica, mas também apagar qualquer resquício de dogmatismo"9. De outro modo, podemos dizer que a metafísica de Schopenhauer é imanente, e não transcendente. Para Schopenhauer, a verdadeira chave para desvendar o que está por trás das aparências é o corpo, nosso objeto imediatamente conhecido, o qual carrega dentro de si a essência íntima do mundo. 0 problema é que o intelecto não é capaz de conhecer tal essência (a vontade), pois sua orientação volta-se exclusivamente para o mundo intuitivo ${ }^{10}$. No fundo, o intelecto é um servo que desconhece completamente o seu amo, de quem recebe ordens e as cumpre, pois "embora tenha aflorado desta [da vontade], [o sujeito do conhecer] reconhece-a como algo diferente de si, como algo estranho (...) Daí explica-se por que o nosso próprio ser é um enigma para nós mesmos, isto é, até para o nosso intelecto" (W II, cap.41, 596). Nesse sentido, Schopenhauer diz que o ser humano é, por excelência, um ser metafísico, pois, na medida em que se "espanta" com sua própria existência e seus atos, sai em busca de respostas. 0 espanto consigo mesmo é próprio dos seres humanos, pois

com o aparecimento da faculdade de razão, logo no ser humano, a essência íntima da natureza chega pela primeira à vez introspecção: então espanta-se com as próprias obras e pergunta-se o que ela mesma é. Mas o espanto dessa "essência íntima da natureza" é tanto mais sério pelo fato de aqui pela

\footnotetext{
${ }^{8}$ Safranski, Op. Cit., 431.

${ }^{9}$ CACCIOLA, Schopenhauer e a questão do dogmatismo, 172.

100 intelecto, por sua vez, pode se libertar da servidão da vontade, como ocorre na contemplação estética e na negação da vontade. Em ambos os casos se trata de conhecimento independente do princípio de razão. No primeiro caso, o indivíduo apreende a Ideia, que é a objetidade mais adequada possível da vontade, podendo daí, no caso do gênio artístico, surgir a produção de uma obra de arte ( $C f$. WI, §34); no segundo caso, através do conhecimento intuitivo do todo da vida, o indivíduo atinge o estado de voluntária renúncia e completa destituição de vontade, fenômeno esse que Schopenhauer designa como ascese (Cf. W I, §68).
} 
primeira vez estar com consciência EM FACE DA MORTE e também se impõe, ao lado da finitude de toda existência, em maior ou menor medida, a vaidade de todo esforço. Com essa introspecção e esse espanto nasce, portanto, a NECESSIDADE DE UMA METAFÍSICA, própria apenas do humano: este é pois um animal metaphysicum. (W II, cap.17, 195; grifo nosso).

Essa necessidade metafísica está bem longe de ser algo irrelevante para Schopenhauer, mas, antes, é uma "necessidade que, forte e inextirpável, pisa os calcanhares da necessidade física" (Id., 197). Schopenhauer não nos deixa dúvidas de que todo indivíduo já se espantou com o mundo e a própria existência, pelo menos, em algum momento da vida. 0 autor observa, porém, que quanto mais baixa for a inteligência de uma pessoa, tanto menos enigmático o mundo e a existência são para ela. Noutros termos, é como se, para essa pessoa, tudo se entendesse por si mesmo. 0 autor explica que, nesse caso, o intelecto permanece inteiramente fiel à sua função de servir à vontade, e a pessoa se sente como parte integrante do mundo e da natureza, não sendo então capaz de se desprender do todo e pensar no mundo como um problema. Mas, de qualquer forma, Schopenhauer nos garante que "até mesmo o indivíduo mais tosco e limitado, em alguns instantes lúcidos" (Id., p.208) espanta-se com o mundo e consigo mesmo, de modo que a ninguém acontece escapar da necessidade metafísica.

Mas, em se tratando de alguém de elevado desenvolvimento de inteligência, ocorre o que Schopenhauer denomina propriamente de "espanto filosófico". Nesse caso, o indivíduo compreende a real gravidade do problema do mundo e da existência, conscientizando-se de que este mundo, com todos os seus males que afligem impiedosamente a humanidade, poderia simplesmente não existir. Para Schopenhauer, a inexistência do mundo não apenas é preferível, mas tão perfeitamente possível quanto a sua existência, por isso, espantamo-nos com a fatalidade que produziu a sua existência. Sendo assim, é importante assinalarmos o caráter angustiante e penoso do espanto, ou seja, ele não consiste numa admiração com ares de alegria, pelo contrário, Schopenhauer o compara ao tom melancólico e nostálgico produzido pelo acorde menor: "o espanto filosófico é, portanto, no fundo, consternado e aflito: a filosofia, como na abertura de Don Juan, começa com um acorde menor" (Id., 209).

Schopenhauer reconhece dois tipos distintos de metafísica, a saber: a filosofia e a religião. Na visão schopenhaueriana, o primeiro tipo de metafísica exige muita reflexão, formação e esforço, por isso, é acessível apenas para um número reduzidíssimo de pessoas; enquanto o segundo tipo atende à maioria da população, dotada da capacidade não de pensar, e sim de acreditar, sendo receptiva não às razões, mas à autoridade (Id., 200). Para Schopenhauer, a filosofia tem a obrigação de ser verdadeira sensu stricto et próprio; já a religião - também denominada de Volksmetaphysik (metafísica popular) -, como está voltada para a massa, deve apresentar uma linguagem simples para que todos a compreendam. E ela assim o faz emprestando a roupagem da fábula e transmitindo a verdade através de alegorias, por isso, Schopenhauer diz que a verdade da religião é sensu allegorico. Mesmo assim, o nosso autor não deixa de ressaltar a importância da religião para a sociedade, como no exemplo a seguir:

as religiões ocupam muito bem o lugar da metafísica em geral, cuja necessidade o ser humano sente como imperiosa, a saber, em parte para termos práticos, como estrela guia das suas ações, como estandarte público da retidão e virtude, nos admiráveis termos de KANT; em parte como consolo indispensável nos duros sofrimentos da vida, nos quais as religiões fazem perfeitamente as vezes de uma metafísica objetivamente verdadeira, na medida em que, tão bem quanto esta, elevam o ser humano acima de si mesmo e da existência temporal: nisso mostra-se luminosamente o grande valor das mesmas, sim, a sua indispensabilidade. (Id., 203; grifo nosso). 
De acordo com Schopenhauer, as metafísicas são eficientes consolos, principalmente, em virtude de seu tratamento dado à vida pós-morte. "O interesse que desperta um sistema filosófico, ou religioso", escreve Schopenhauer, "tem o seu mais forte ponto de atração absolutamente no dogma de algum tipo de perduração após a morte" (Id., 196). É por isso que, na visão schopenhaueriana, os sistemas materialistas ou céticos nunca sobreviveram de modo duradouro; as religiões, em contrapartida, como sempre vincularam a nossa existência ao dogma que realmente nos importa, o da imortalidade, nunca sucumbiram. Nesse sentido, dizemos que as metafísicas nos consolam, porque nos fornecem uma crença sobre o que supostamente encontraremos pós-morte, e isso faz com que olhemos a própria morte de um modo diferente, se não mais agradável, pelo menos, menos agressivo.

Mas o fato de Schopenhauer considerar a filosofia e a religião como metafísicas não significa que ele valoriza todas elas. 0 autor desdenha peremptoriamente o que chama de metafísicas otimistas, as quais incluem, por exemplo, o panteísmo, os sistemas de Leibniz e Hegel, bem como o judaísmo, paganismo e islamismo (a pior de todas as religiões, na visão de Schopenhauer). Por outro lado, Schopenhauer nos assegura que aquela necessidade metafísica, tão forte e inextirpável em nós, na maioria das vezes, se satisfaz com metafísicas bem ruins, então, por pior que seja uma metafísica, aos olhos do nosso autor, ainda assim ela é capaz de cumprir satisfatoriamente a sua função, como o próprio Schopenhauer nota a seguir:

considere-se, por exemplo, o Corão: esse livro ruim foi suficiente para fundar uma religião mundial, satisfazer há mais de 1.200 anos a necessidade metafísica de incontáveis milhões de pessoas, tornar-se o fundamento da sua moral e de um significativo desprezo pela morte, bem como entusiasmá-las a sangrentas guerras e às mais amplas conquistas. (...) Muito se perde durante as traduções; mas eu não pude descobrir ali um pensamento sequer de valor. 0 que prova que a necessidade metafísica não anda de mãos dadas com a capacidade metafísica (Id., p. 197).

De outro modo, podemos associar essa capacidade metafísica àquilo que Schopenhauer chama nos Aforismos de tipos de pessoas (P I, 337-8, dentre outras), e assim dizemos que diferentes tipos de pessoas se identificam com diferentes tipos de metafísicas. Se considerarmos, por exemplo, o que Schopenhauer denomina de "ser humano vulgar", veremos que se trata de alguém com entendimento rude e limitado. Nesse caso, de acordo com o nosso autor, a filosofia lhe seria inconcebível e assim insatisfatória como metafísica. Donde concluímos que a metafísica popular é a que melhor lhe conviria. É nesse sentido, portanto, que entendemos por que o autor afirma que UMA SÓ metafísica não pode ser satisfatória a todos (W II, cap. 17, 200). De qualquer forma, Schopenhauer se mostra bastante confiante de que haverá, em meio a tantas filosofias e religiões, ao menos, uma metafísica com a qual o indivíduo poderá se identificar e se consolar em face da certeza assustadora da morte, pois "principalmente para esse fim", afirma Schopenhauer,

estão orientadas todas as religiões e todos os sistemas filosóficos, que são, portanto, antes de tudo, o antídoto contra a certeza da morte, fornecido pela razão reflexionante a partir dos próprios meios. 0 grau, no entanto, em que atingem esse fim é bastante diverso, e com certeza UMA religião ou filosofia capacitará o ser humano, muito mais do que outra, a lançar um olhar tranquilo para a face da morte (W II, 41, 555; grifo nosso).

Sendo assim, se olhássemos para a campanha "fica em casa!" contra o covid-19, sob o viés schopenhaueriano, acrescentaríamos "no abrigo de uma metafísica", pois as aglomerações sociais o nosso autor já as evitava costumeiramente e, além disso, acreditamos que, se Schopenhauer fosse nos recomendar uma boa companhia neste momento, certamente seria uma metafísica. 


\section{Consideração final}

O inestimável valor das metafísicas, tão enaltecido por Schopenhauer, não se estende, porém, a seus representantes. Na verdade, o autor observa um problema bastante comum: "nunca faltaram tipos que se esforçavam em tirar o seu sustento daquela necessidade metafísica do ser humano e explorá-la ao máximo; por isso em todos os povos há monopolistas e grandes arrendatários dela: os sacerdotes" (WII, cap.17, 198). Por meio dessa crítica, Schopenhauer denuncia aqueles representantes da religião que sempre souberam explorar a necessidade metafísica do povo, como bem quiseram. Mas também na filosofia há, segundo o nosso autor, aproveitadores que tiram o seu sustento da nossa necessidade metafísica, os quais Schopenhauer denomina de professores de filosofia, alugados para os fins do Estado: "esses negociantes de cátedra... tomaram posse do mercado e já providenciaram para que aqui nada valha a não ser o que eles deixam valer, portanto, méritos apenas existem se eles e sua mediocridade estimarem reconhecer" (P I, 149) ${ }^{11}$.

Do nosso ponto de vista, essa crítica schopenhaueriana, dirigida aos exploradores de ambas as metafísicas, deve sempre ser lembrada, principalmente, àquela pessoa que se mostra insatisfeita com a filosofia e a religião como metafísicas na atualidade, alegando que as filosofias em voga e as religiões atuais estão bem aquém do que Schopenhauer certamente admiraria. Argumentando a seu favor, essa mesma pessoa pode nos convidar a entrar numa livraria, onde lá ela aponta para as estantes de livros de filosofia mais vendidos e diz que eles não passam daquilo que Schopenhauer chamaria de produtos de negociantes, visando unicamente fins lucrativos. A mesma decepção, essa pessoa encontra nas estantes das religiões, pois afirma que elas, hoje em dia, seduzem os seus leitores, principalmente, através de livros sobre o fim do sofrimento e a arte da felicidade em cinco passos, misturando dogmas e conceitos filosóficos num tipo de pensamento que Schopenhauer chamaria de "estranho hermafrodita ou centauro" (W II, cap.17, 204). A essa pessoa, lembramos que já na época de Schopenhauer era assim, como o próprio autor denuncia nas citações acima: os representantes das metafísicas sempre fizeram da necessidade metafísica da humanidade um comércio bastante lucrativo. Ressaltamos, porém, que essa atitude de seus representantes não tem relação com as metafísicas em si mesmas, que são notáveis para o nosso autor. Ademais, Schopenhauer nos ensina que não necessariamente temos de recorrer às metafísicas da atualidade, o autor diz, aliás, que, nos tempos primevos, a humanidade foi capaz de "saciar de uma maneira mais digna a necessidade metafísica: assim, nasceram naqueles ancestrais dos brāhmanas, os rishis, as concepções quase supra-humanas que depois foram depositadas nos Upanishads dos VEDAS" (Id., 198). Assim, com Schopenhauer aprendemos que as verdadeiras metafísicas jamais envelhecem. E é precisamente por acreditar que o mesmo pode ser dito sobre a metafísica de Schopenhauer que nós a abordamos aqui, no atual contexto.

\section{Referências}

BARBOZA, J. Schopenhauer. A decifração do enigma do mundo. São Paulo: Moderna, 1a. edição, 1997.

CACCIOLA, M. L. Schopenhauer e a questão do dogmatismo. São Paulo: EDUSP/FAPESP, 1994.

\footnotetext{
11 Sobre esse assunto, ver: PICOLI, G. T. Schopenhauer e o misticismo: sobre suas supostas críticas apimentadas à religião. Voluntas: Revista Internacional de Filosofia, Santa Maria, v. 9, n. 2, p. 84-92, jul-dez. 2018. Disponível em: <https://periodicos.ufsm.br/voluntas/article/view/35568/pdf>.
} 
GWINNER. Arthur Schopenhauer aus persönlichem Umgang dargestellt. Norderstedt: Verlag der Wissenschaften, 2015.

JANAWAY, C. Schopenhauer. Tradução de Adail Ubirajara Sobral. São Paulo: Edições Loyola, 2003.

PICOLI, G. T. Schopenhauer e o misticismo: sobre suas supostas críticas apimentadas à religião. Voluntas: Revista Internacional de Filosofia, Santa Maria, v. 9, n. 2, p. 84-92, jul-dez. 2018. Disponível em: <https://periodicos.ufsm.br/voluntas/article/view/35568/pdf>.

SAFRANSKI, R. Schopenhauer und die wilden Jahre der Philosophie. Frankfurt am Main: Fisher Verlag, 2001.

SCHOPENHAUER, A. Aphorismen zur Lebensweisheit. In: Parerga und Paralipomena I. Zürich: Haffmans, 1988. Edição "letzter Hand" de Ludger Lütkehaus.

SCHOPENHAUER, A. Cholerabuch. Würzburg: Königshausen \& Neumann, 2017.

SCHOPENHAUER, A. Cogitata. Würzburg: Königshausen \& Neumann, 2017.

SCHOPENHAUER, A. Da vaidade e do sofrimento da vida. In: $O$ mundo como vontade e como representação, tomo II, 1a. edição. Tradução de Jair Barboza. São Paulo: UNESP, 2015.

SCHOPENHAUER, A. Do primado da vontade na consciência de si. In: O mundo como vontade e como representação, tomo II, 1a. edição. Tradução de Jair Barboza. São Paulo: UNESP, 2015.

SCHOPENHAUER, A. Nachträge zur Lehre vom Leiden der Welt. Parerga und Paralipomena II. Zürich: Haffmans, 1988. Edição "letzter Hand” de Ludger Lütkehaus.

SCHOPENHAUER, A. O mundo como vontade e como representação, tomo I, 1a․ edição. Tradução de Jair Barboza. São Paulo: UNESP, 2005.

SCHOPENHAUER, A. Sobre a morte e sua relação com a indestrutibilidade de nosso ser em si. In: $O$ mundo como vontade e como representação, tomo II, 1a. edição. Tradução de Jair Barboza. São Paulo: UNESP, 2015.

SCHOPENHAUER, A. Sobre a necessidade metafísica do ser humano. In: O mundo como vontade e como representação, tomo II, 1a. edição. Tradução de Jair Barboza. São Paulo: UNESP, 2015.

SCHOPENHAUER, A. Ueber die Üniversitäts-Philosophie. In: Parerga und Paralipomena I. Zürich: Haffmans, 1988. Edição “letzter Hand” de Ludger Lütkehaus.

WEISSMANN, K. Vida de Schopenhauer. Belo Horizonte, MG: Cultura brasileira, 1945.

ZIEGLER, E. In: SCHOPENHAUER, A. Cholerabuch. Würzburg: Königshausen \& Neumann, 2017. 